\title{
Drugost ženskog/vještičjeg tijela: institucionalne prakse o(d)značivanja
}

\section{Abstract: Otherness of Women's/Witches' Bodies: Institutional Practices of (De)Signification}

This text discusses the discursive construction of the body of a woman/witch as a threatening Other under Article 60 of the Criminal Practice, which served both as a criminal law and as a criminal procedure law in Hungary, and thus Croatia and Slavonia, during the period of mass witchcraft trials from 1699 to the mid-18th century. Otherness is approached from a psychoanalytic, Lacanian point of view because it opens up the possibility of understanding the collective affective politics of fear as a reflection of the unconscious in the language that created the witch imaginary, which takes its origin from the register of the imaginary and the mirror stage, i.e., in the psychological economy of structuring of the self/ego. The legal procedures that are analyzed in the text as part of the symbolic register seek to socially channel and discipline fear first by inscribing on and into women's bodies various deviations and transgressions of the human, which are then entirely annulled through designification procedures and practices ${ }^{[1]}$ Keywords: body, witch, devil, devil's mark, the Other, fear, Croatia, Criminal Practice, torture, psychoanalysis, Lacan

Različiti dokumenti iz doba progona vještica poput demonoloških traktata, ${ }^{[2]}$ zakona i procedura isprva crkvenih, a kasnije i sekularnih pravnih struktura te zapisnika sa suđenja ukazuju na dijeljeno neuralgično mjesto, a to je odnos prema (ponajprije) ženskom tijelu i tjelesnosti. Konstrukcije i reprezentacije nekih tijela kao ne-ljudskih, odnosno označenih ne-ljudskima, a koja tako postaju unheimlich ili, lakanovskom terminologijom - prijeteća Drugost - i kulminiraju 
vještičjim imaginarijem nije tek specifičnost hrvatskih procesa koji su postali masovnima u razdoblju od 1699. do sredine 18. stoljeća ${ }^{[3]}$ nego je zajednička u većem dijelu Europe od kasne renesanse do ranoga novoga vijeka. Fiksacija na transgresivno, devijantno, zastrašujuće tijelo s neprirodnim sposobnostima koje je središtem imaginarija praćena je cenzuriranjem, nadziranjem i discipliniranjem tijela i seksualnosti u teološkome, pa onda i u javnom (ili sekularnom) diskursu, koji je ipak znatno obilježen reformacijskim, odnosno u Hrvatskoj protureformacijskim odjecima[4] lako su masovni progoni vještica do sada pretreseni iz različitih disciplinarnih očišta i tematskih čvorišta, problem korporalnosti i problematična korporalnost rijetko su bili fokusom istraživanja, a još manje iz psihoanalitičke vizure. To s jedne strane i nije neobično, jer su psihoanaliza, pa i psihoanalitička kritika usmjerene ponajprije na probleme psihičkih struktura. No s druge strane, Freudovo utemeljenje psihoanalize počiva na promatranju tijela, tjelesnih simptoma i manifestacija prvotno histerične konverzije, što je dovelo do konceptualizacije nesvjesnog, teorije o nagonima, terapije razgovorom; drugim riječima psihoanaliza jest utemeljena upravo u hermenutici tijela. Nastavljajući se na Freuda, i Lacan je posvetio tijelu znatnu pozornost, ponajprije u definiranju psihičkih registara ${ }^{[5]}$ On dovodi u pitanje kartezijanski radikaliziranu distinkciju tijela i uma, tijela i ega, pa onda i tijela i subjekta, ukazujući da su međusobno povezani (dijelom i suprotstavljeni), ali i upućuje da rijetko imamo posla s fizičkim, stvarnim tijelom: ono nije nešto što imamo ili posjedujemo, smatra Lacan, nego je nešto što nam je dodijeljeno i označeno Drugim, prije svega jezikom (Écrits 92-100; 490-526). Odnosno, kako piše Fink, u procesu subjektivizacije „tijelo je pokoreno, 'pismo ubija' tijelo. 'Živo biće' (le vivant) - naša animalna priroda - umire, a jezik oživljava na našem mjestu i živi nas. Tijelo se, takoreći, ponovno ispisuje, fiziologija uzmiče pred označiteljem, a svi naši tjelesni užitci počinju upućivati na odnos prema Drugom i uključivati ga" $(14)$.

Upravo tu označenost Drugim, što je važan Lacanov doprinos ne samo psihoanalizi, nego i razumijevanju uloge nesvjesnoga u društvenim i kulturnim dodjeljivanjima značenja tijelima, smatram važnim teorijskim polazištem da bi se razumjelo diskurzivne konstrukcije tijela i predodžbe o njemu u doba masovnih progona vještica, razdoblju u kojem su vještičja tijela postala prijelomnim mjestom upisivanja, ali i sukoba različitih sustava moći. 
Lacanov pristup korporalnosti objedinjuje sociološke i antropološke studije tijela, ali im dodaje i važnu dimenziju - onu psihičkih struktura subjektiviteta i utjecaja nesvjesnoga na tijelo, a koji su u neprestanoj međuigri s izvanjskim svijetom [6] Za Lacana je tijelo primarno jezik koji ga stvara te se tijelo „dodjeljuje” subjektu u trenutku ulaska u svijet društva i kulture posredstvom označitelja; tijelo je potrebno utjeloviti, inače je ono tek organizam. Subjekt i tijelo su načini upisivanja u simbolički poredak i njegove transmutacije posredstvom Drugoga. Tako se lakanovska i postlakanovska psihoanaliza bave izgovorenim tijelom, odnosno tijelom koje govori (corps parlant), koje je upleteno u mrežu označitelja putem ponajprije jezika; odnosno kako smatra Lacan, jezik je „suptilno tijelo, ali ipak jest tijelo" (Écrits 248), ono je Drugost koju je stvorio Drugi, odnosno jezik, kultura i društvo u koje je subjekt uronjen.

\section{Tijelo Drugoga}

Razdoblje ranoga novoga vijeka i masovnih progona vještica ukazuje na radikalizirani problem Drugosti tijela, odnosno tijela Drugoga koje je konstruirano različitim diskurzivnim, jezičnim praksama koje nastoje jasno razgraničiti ljudsko od ne-ljudskoga, odnosno regulirati i premrežiti tijela dominantnim ideološkim i afektivnim politikama. Neke od tih diskurzivnih praksi posve su nove lakune u povijesti konstruiranja tijela i tjelesnosti te kanonizirane u različitim službenim, institucionalnim tekstovima i dokumentima, dok su pak neke kanonizirane u vizualnim umjetnostima ${ }^{[7]}$ koje su potom povratno utjecale na reprezentaciju tijela vještica i u nefikcijskim tekstovima, pa i na cijeli afektivno obilježen kulturni imaginarij. Strah od vještica zgušnjava se upravo u predodžbama o njihovu tijelu - sposobnosti transmutacije i transvekcije, obilježenosti đavoljom sveprisutnošću, između ostalih, i predodžbama o tome što njihova tijela mogu činiti drugim, normalnim tijelima - od infanticida, kanibalizma, fragmentacije i poništavanja do označivanja ljudskih tijela izvanljudskim označiteljem. Te predodžbe, premda čine kumulativni vještičji imaginarij, svoje izvorište imaju u različitim diskurzivnim sustavima - teološkom, demonološkom, pravnom i vernakularnom, pa i medicinskom, a koje nije moguće uvijek jasno razgraničiti, no u ovome radu fokus je stavljen na sekularno pravno konstruiranje tijela vještice koje ima svoju differentia specifica i koje se može razumjeti, s jedne strane, kao proces uspostavljanja 
društvene i političke moći, no koje se, s druge strane, može tumačiti i kao strukturiranje subjektiviteta uz pomoć specifične, ranonovovjekovne Drugosti.

Za institucionalni odnos prema tijelu vještice u Hrvatskoj, odnosno za jurističko upisivanje predodžbi o vještičjem tijelu i njegovim devijacijama bila su ipak najvažnija dva zakona, Praxis criminalis iz 1697. te kasniji Opći zakon o kaznenom sudskom postupku Marije Terezije iz 1768., s posebnim dijelom posvećenim propisima o čarobnjaštvu, a koji je važan ponajprije jer je ograničio pravo lokalnih sudova da pokreću procese, ali nije označio i kraj progona.

\section{Kriminalna praksa: pravni diskurs i označivanje (ne)ljudskoga tijela}

Prvi zakon, djelatan u doba masovnih progona, a dijelom i njihov glavni pokretač, Praxis criminalis, punoga naziva Forma processus iudicii criminalis seu Praxis criminalis, ili dalje u tekstu Kriminalna praksa, latinski je prijevod zakonika o kaznenom postupku kralja Ferdinanda III. za Donju Austriju, a važio je kao pisani dokument običajnoga prava i za Ugarsku, dakle i Hrvatsku i Slavoniju te je, iako nastao 1656., uvršten 1697. i u Zbornik prava Ugarske i pripojenih joj zemalja. Kriminalna praksa istodobno je bila kazneni zakonik i zakonik o kaznenom postupku, a sadrži i propise o postupcima protiv čarobnjaštva, osobito članak $60^{[8]}$ Premda je zakon rodno neutralan, odnosno izrijekom navodi i „čarobnjake” i „vještice” kao moguće počinitelje zločina, hrvatski procesi vođeni su gotovo isključivo protiv žena koje su već zakonskim procedurama obilježene kao Drugost (ponajprije kao tijela) i to kao Drugost obilježena đavlom.

Vještici kao velikom Drugom pridružen je đavao, kojeg se može odrediti kao das Ding, stvar, kao ono što je dio realnoga pa je time i „onkraj označenoga” i onkraj/izvan jezika; ona je naprosto nespoznatljivi x, mimo i izvan simbolizacije (Lacan, Le Séminaire 54). Ta stvar, das Ding, kao đavao je glavna prijetnja uređenome društvu ili pokušajima uređivanja društva jer je usko povezan s jouissance, a sam je neuhvatljiv i nedodirljiv te unosi kaos i razdor, ali svoj materijalni trag ostavlja na vještičjim tijelima koje su, za razliku od njega, uhvatljive i koje je moguće sankcionirati. Na tu predodžbu upućuje stavak 2. članka 60 . Kriminalne prakse, u kojem su opisane okolnosti i razlozi pritvaranja sumnjivih osoba, u kojem se navodi sljedeće: „Ako takve stvari pronađe, može 
dalje postupati i pobrinuti se da krvnik pomno pregleda i pretraži tijelo [okrivljene osobe] nema li na tijelu na skrivenom mjestu tajne predmete ili kakve druge prave demonske znakove" (nav. prema Bayer 568).

\section{3. Đavao i njegov znak}

Sama predodžba o „demonskome znaku”, koji je najčešće označivao đavolji, vražji pečat (stigma diabolicum) ugovora koji vještica s njime sklapa i čime pristaje na herezu i apostaziju, nejasnog je porijekla i mnogo se češće javlja u procesima vođenima tijekom 17. stoljeća, iako je praksa detaljnoga pregleda tijela započela već u 15. stoljeću na suđenjima u Freiburgu, odakle se širila dalje. Ipak, najvažniji demonološki traktati poput Kramerovog Malleus maleficaruma izrijekom ga ne spominju, u procesima koje je vodila inkvizicija nije osobito važan, ali zato ga obilno i nezaobilazno koristi većina sekularnih sudova diljem Europe (Monter 275-77), ${ }^{[9]}$ pa tako i u Hrvatskoj.

S obzirom na to da su masovni progoni započeli kada su sekularni sudovi u potpunosti prihvatili, odnosno preuzeli teološku definiciju zločina vještičarstva, dok su dotad sankcionirali isključivo maleficij, čini se da je novi element - đavolji pečat - koji je okosnica Kriminalne prakse, a koji se ne pojavljuje kao dio crkvenoga pravnoga reguliranja i definiranja zločina - nova strategija sekularnoga, institucionalnoga označivanja i zaposjedanja tijela. Tako koncept demonskoga ugovora i njegova vizualnoga, materijalnoga aspekta, đavoljeg pečata postaju društveno-pravna kodifikacija drukčijeg tijela koje izlazi iz okvira normalnoga i prihvatljivoga, civiliziranoga i discipliniranog, a znak na koži vještice izvanjski je aspekt i potvrda onoga unutarnjega, devijantnog, što je nužno izopćiti i korigirati, odnosno kazniti. Izvanjsko obilježje vještičjega i ženskoga kao ne-ljudskoga konstrukcija je pravnoga diskursa koji na taj način određena tijela smješta na rubnu poziciju simboličkoga, mapira ih i regulira, odnosno marginalizira te ih stavlja u submisivni položaj unutar (muškoga) državnoga aparata moći. Odnosno, kako smatra Silvia Federici u knjizi Caliban and The Witch, progoni vještica bili su nasilne strategije discipliniranja i aproprijacije ženskoga tijela te su pokazivali kako su upravo tijela bila glavnim mjestom upotrebe novih tehnika moći, oko kojih se razvila osobito elaborirana procedura i aparatura torture, a koja je, pak, usmjerena na fragmentirano tijelo i fragmente tijela. Upravo su reprezentacije fragmentiranih 
tijela, odnosno tijela u komadima (ono što Lacan naziva corps morcelé), njegovi različiti dijelovi bili važnim toposom vještičjega imaginarija ${ }^{[10]}$ i to najčešće ljudske (ili ponekad i životinjske) kosti, (uglavnom dječje) lubanje od kojih su spravljale mast ili ulje, i - kao osobit novovjekovni strah penisi koje su vještice, prema autoru Malleusa, krale, dok su se ostalim dijelovima tijela koristile za vradžbine, proricanja ili pak letenje. Taj se dijeljeni, kolektivni strah od fragmentacije i dezintegracije tijela zrcalio i u samome zakonu (i drugim zakonima diljem Europe), kojim ga se nastojalo nadvladati, odnosno, točnije, staviti isključivo pod kontrolu državnih aparata moći i to prvo upisivanjem Drugosti određenim tijelima, a potom i njihovim fragmentiranjem. Posjedovanje komada tijela, bilo životinjskih bilo ljudskih, ili navodnih pripravaka od njih bilo je dostatnim markerom transgresije, što je izrijekom upisano i u Kriminalnoj praksi u dijelu koji se odnosi na zatvaranje sumnjivih osoba, u paragrafu 2. :

Kada se prema tome istragom otkrije da zločin, šteta i ostale okolnosti, zbog kojih je neka osoba bila sumnjiva, zaista postoje, sudac može sumnjivu osobu zatvoriti. Ujedno se treba pridržavati slijedećega:

Prvo. Da, što je moguće prije, kada [sumnjivu osobu] zatvori, pretraži njezinu odjeću, kuću i stan, i da se pobrine da pregleda ima li ona kod sebe ili u svojoj blizini kakve čarobnjačke predmete kao na primjer: ulje, masti, škodljive praške, lonce kukaca, ljudske kosti, čarobne svjetiljke i voštanice, slike probodene iglama, hostije, kristale, gatalačka ogledala, listove papira koji sadrže ugovor s demonom, knjige o čarobnjačkim umijećima i slično. (Bayer 567)

Samo posjedovanje fragmenata tijela ili pripravaka od određenih dijelova kojima se izvodi maleficij ili se uz njihovu pomoć može izvoditi nešto izvan, odnosno ne-ljudsko, proizvodi strah čije ovladavanje nije samo važan segment pravnoga diskursa, nego i utemeljenja subjektiviteta. Naime, lakanovskom terminologijom, strah od fragmentiranoga tijela - te zastrašujuće slike zasebnih dijelova idealne cjeline - cijeli reprezentacijski kolaps zapravo su strah od predsimboličkoga kaosa i svoje izvorište imaju u registru imaginarnoga, to jest u stadiju zrcala. Prema Lacanu, u stadiju zrcala subjekt (koji to još nije) doživljava svoje tijelo kao podijeljeno i fragmentirano, što pak proizvodi tjeskobu koja ga nagoni da se u konačnici identificira sa svojim zrcalnim odrazom, a što označava formiranje sebstva/ega ("Le stade" 92-100). No kako navodi 
Evans, anticipacija sintetskoga ega stoga je neprestano ugrožena sjećanjima na osjećaj fragementiranosti koji se odražava u „slikama kastracije, emaskulacije, mutilacije, komadanja udova, dislokacije, evisceracije, proždiranja, rasprskavanja tijela" (Lacan, "Le stade" 104), slikama koje trajno nastanjuju imaginaciju i fantazije i koje podsjećaju da je tijelo kontinuirano podijeljeno „imaginarnom anatomijom”. Ono što nastaje, izranja iz stadija zrcala, nije samo slika sebstva koje zaposjeda čitavo, ujedinjeno tijelo nego i, preko Imena Oca, odnosno zakona, cijeli registar simboličkoga, kulture i društva, sebstva i Drugosti, dopuštenoga i zabranjenoga. Fantazije i pripadajući im strahovi iz stadija zrcala i registra imaginarnoga neobično su nalik na vještičji imaginarij: da bi se njima ovladalo, potreban je zakon koji će in regulirati, stavljajući vještice u poziciju onih čija tijela bivaju fragmentiranima i u konačnici poništenima, čime se uspostavlja novi red u širem društvenom kontekstu.

No samo posjedovanje dijelova tuđih tijela i demonski pečat nisu jedine strategije diskurzivnoga oblikovanja vještičje Drugosti. Njezino tijelo obilježeno demonskim tragom ima svoje osobitosti kojima se razlikuje od normalnoga, ljudskoga tijela, što je vidljivo u sljedećem paragrafu Kriminalne prakse - „Osnovi sumnje dovoljne za mučenje”, koji pak prethodi proceduri mučenja odnosno odznačivanja tijela vještice:

Prvo. Kada se takve stvari ili znakovi pronađu u kući ili na tijelu.

Drugo. Kada postoji dokaz da se [okrivljena osoba] drugima ponudila da će ih učiti čarobnjaštvu. Treće. Ili kada se nekome zaprijetila da će mu čarobnjaštvom učiniti zlo, pa ako se tome takvo zlo dogodi.

Četvrto. Ili ako se naročito družila s takvim čarobnjacima.

Peto. Ili je vršila takve sumnjive stvari, kretnje, riječi i čine s kojima je spojeno čarobnjaštvo, pa je zbog toga inače sumnjiva.

Šesto. Ili ako se ta osoba po noći, u određeno vrijeme, ne može pronaći u kući u kojoj su vrata zaključana, a ne može se s druge strane dokazati gdje je ona inače u to vrijeme bila.

Tada onaj kome pripada sudbena vlast, nakon prethodno provedene istrage, ustanovljuje da li prema izvršenom istraživanju proizlazi da je sve to stvarno tako, pa nakon što donese međutomnu presudu može pristupiti mučenju [okrivljene osobe] i pri tome se poslužiti ovim pitanjima. (Bayer 
Ovim dijelom zakona ne određuje se samo tijelo vještice kao izopačeno jer je obilježeno i pečatirano, nego pak i njezino kretanje, djelovanje, ali i sam jezik kojim se ona koristi, a kojemu se tako priznaje magijski potencijal da stvara i iscjeljuje, no s druge strane, i da uništava. Zakonsko određivanje nekih riječi kao „sumnjivih”, kao onih koje imaju malefičnu moć, moguće je interpretirati oslanjajući se na lakanovsku tezu o smrtonosnim svojstvima pisma/jezika koje ubija realno, a koje je bilo prije riječi i prije jezika, odnosno koje dovodi subjekt u poziciju označenosti, premreženosti različitim označiteljima. Kao što smatra Fink nastavljajući se na Lacana: „Tijelo se kroz socijalizaciju postupno ispisuje ili preispisuje označiteljima, užitak se smješta u neke zone, dok se druge zone neutraliziraju riječju i privoljavaju na suglasnost s društvenim normama ponašanja" (29). Društvena konstrukcija stvarnosti/realnosti, pa onda i društvene norme, proizvod su jezika: ono što se ne može iskazati jezikom naprosto ne može biti dijelom te realnosti, jer tek jezik daje stvarima egzistenciju. ${ }^{[1]}$ Vještičja moć da uz pomoć jezika, odnosno riječi, o(d)značuje tijela drugih subjekata, da ih tako može poništiti, izmijeniti ili im naškoditi jest prijetnja cijelom simboličkom poretku i označava razaranje društvenoga tkiva, a pravni diskurs tu moć prepoznaje i sankcionira koristeći se upravo jezikom kako bi povratno označio i konstruirao određene zone vještičjega tijela, stavljajući time i sam jezik pod vlastitu kontrolu.

$U$ istome paragrafu pod točkom šest vještičje tijelo dodatno se diskurzivno oblikuje predodžbom da posjeduje sposobnost nestajanja ili letenja i pojavljivanja na drugome mjestu, odnosno transvekcije, sposobnost koju normalna, regularna ljudska tijela, dakako, nemaju. Ta se predodžba uglavljuje u pravnome diskursu, iako njezini korijeni sežu do antike, bar što se tiče pisanih izvora[12] i prepleće se s pučkim vjerovanjima i kultovima, a kasnije i teološkim diskursom da bi svoje konačne obrise dobila upravo u doba masovnih progona, kad postaje stalnim toposom imaginarija. Sublimnost tijela vještice koja nije sposobna samo riječima poništiti ili izmijeniti simbolički poredak, nego posjeduje i moć koja nadilazi i realno kao biološku funkciju, tijelo kao organizam sa svojim fizičkim i fiziološkim danostima, izranja iz zakonskih regulativa kao jedan od važnih strahova ranoga novoga vijeka, strah od čudovišnoga ženskog tijela koje se daljnjim procedurama nastoji ne samo odznačiti, nego i gotovo atomizirati, a potom i u potpunosti poništiti. Na to upućuje segment iz Kriminalne prakse koji propisuje detaljna pitanja koja se postavljaju tijekom torture: 
Pitanja (koja se okrivljenoj osobi stavljaju na mukama)

$$
\iint 4
$$

1) Nema li ugovor s demonom?

2) U kojem obliku [je taj ugovor sklopljen]?

3) Kada je sklopljen?

4) Na koje vrijeme?

5) Da li je sklopljen pismeno ili usmeno?

6) Na kojem mjestu?

7) S kojom namjerom i u kojoj prigodi?

8) Je li tko bio prisutan?

9) Gdje je ugovor ili kakav znak od njega ima?

10) Što ju je na to potaklo?

11) Da li je vršila čarobnjačke čine?

12) Na koji način i kako? Ovdje treba primijetiti da treba dozvoliti da najprije [okrivljena] osoba sama govori i iskazuje, ako pak na iznesene osnove sumnje ništa ne izjavi, tada je treba ispitati prema svim okolnostima stvari.

13) Kojim je riječima ili djelima čarala? (Ako okrivljena osoba navede da [je nešto] zakopala i spremila što je dovodi u vezu s čarobnjaštvom, treba potražiti ne bi li se našlo).

14) Koliko puta?

15) Na kojim mjestima?

16) Kada ili u koje vrijeme?

17) Prema kojoj osobi? (Imena različitih osoba treba pomno napismeno zabilježiti da se može istraživati.)

18) Kome je čarobnjaštvom naškodila, kako teško?

19) Može li pomoći osobi kojoj je čarobnjaštvom nanijela zlo? (Ovdje treba primijetiti da je dozvoljena samo ona pomoć koja se može izvesti bez novog čarobnjaštva.)

20) Od koga je naučila čarobnjačko umijeće? Kako je do toga došlo? Nije li ona sama druge učila čarobnjaštvu? Koga? Kako? Pitati treba i drugo na što možda ukazuju činjenice i njihove okolnosti. Nakon što je izvršeno ispitivanje i dat iskaz neka onaj kome pripada sudbena vlast što je moguće 
prije, svagdje istražuje ne bi li se našli znakovi ili zakopane odnosne tajne stvari, te da li je doista čarobnjaštvom naneseno zlo ili šteta ljudima i stoci. Ne može se, naime, vjerovati samome iskazu koga stvarnost ne potkrjepljuje.

Istraživanje hladnom vodom kao nesigurna stvar, izvrgnuta mogućnosti prevare, ne smije se primijeniti.

Isto tako, [treba paziti] da li postoji izričit ugovor s demonom.

Ili da li je bez izričitog ugovora od nekoga naučila i vršila [čarobnjaštvo], zato da time drugima škodi?

Ili da li je bez nanošenje štete, u svrhu zarade, ljudima gatala iz kristala, ogledala i sličnih predmeta?

Ili da li se samo služila supersticioznim blagoslivljanjima?

Ili da li je znala ili mogla prenositi ljude na jarcu, plaštu ili lađama?

\section{Konačna presuda}

Zločin naime pravog čarobnjaštva zaslužuje kaznu smrti spaljivanjem bilo da se vrši po izričitom ili prešutnom ugovoru s demonom, pa se njime ljudima nanosi šteta, bilo da ga vrše oni čarobnjaci, koji se uz odricanje od kršćanske vjere predaju demonu ili s njime spolno opće, premda inače svojim čarobnjačkim zlodjelima nikome nisu nanijeli štetu. Ipak ako postoje važne okolnosti i kada šteta nije teška, ta se kazna može ublažiti onima koji se pokaju, time da im se prethodno odsiječe glava.

Gatari, oni koji se služe supersticioznim blagoslivljanjima i oni koji na jarcu jaše, mogu se prema težini kažnjivog djela kazniti odrubljivanjem glave ili, kada šteta i okolnosti nisu veoma teške, mogu se otpraviti s potpunim ili polovičnim brojem šiba i ujedno protjerati iz pokrajine. (Bayer 568-70)

\section{4. Ženska čudovišnost i đavolja moć}

U ovome dijelu pravnoga diskursa dodatno se konstruira i proširuje čudovišnost tijela ne samo na sposobnost transvekcije, nego i na sposobnost da druge prenosi na „jarcu, plaštu ili lađama”, to jest na elemente koji pripadaju i folklornoj tradiciji i teološkom diskursu i vizualnim umjetnostima. Simbolika životinje - jarca - u doba masovnih progona imala je dvojnu funkciju: konceptualizira ga 
se, uz metlu, kao najčešće „prijevozno sredstvo” vještica ili pak kao obličje u kojem se pojavljivao vrag. Dok je u rimskoj, grčkoj i keltskoj mitologiji jarac bio uglavnom simbolom životnoga elana i plodnosti te kojega se žrtvovalo u okviru kultova nekih božanstava, u kršćanstvu on zadobiva negativno značenje i postaje simbolom požude i razvrata. U Novome zavjetu jarac je zla životinja kojoj su nasuprot dobre ovce i za Posljednjega suda smješten je na lijevu stranu predstavljajući grešnike, odnosno sve loše kršćane. Tijekom srednjeg vijeka uglavljuje se među životinjama koje reprezentiraju vraga, uz zmiju, zmaja i psa, dok demonološki traktati iz doba progona meandriraju između mačke, psa, konja, muhe i čovjeka, ali najčešće upravo jarca (usp. Zika, „Goat” 446-47). Spominje ga i Nicolas Rémy u svojoj Demonolatriji iz 1595., u kojoj piše da se vrag može pojavljivati u tijelu različitih životinja, ali je najčešće prisutan na ceremonijama u obliku jarca jer se „opscena lascivnost” sabata najviše podudara s njegovom dijaboličkom prirodom (nav. prema Zika, „Goat” 446). Samo neprirodno združivanje čovjeka, odnosno vještice sa životinjom, pri čemu oboje imaju fantastične sposobnosti, pridonosi izgradnji njezine izglobljenosti iz ljudskoga te njezinu korporalnost čini dodatno zazornom jer je sublimna, odnosno ona je reprezentacija bezgraničnosti, za razliku od reguliranih, normalnih tijela koja su omeđena, ograničena materijalnom stvarnošću i fizikalnim zakonima. Vještičja čudovišnost tako se sastoji ne samo od njezinih ne-ljudskih sposobnosti i moći, nego je čudovišna jer je onkraj poznatoga i sigurnoga, nalik ljudskome i utemeljena u njemu, a istodobno posve drukčija. Prelaženjem ili mijenjanjem granica vlastita tijela, sama ili uz pomoć životinje, vještica narušava granice prostora ljudskoga te prijeti raspadom cijelome društvu: njezino mijenjanje obličja te ponovno uspostavljanje sebe same kao vješticečovjeka-subjekta prema potrebi sugerira njezinu sposobnost manipuliranja vremenom i prostorom, odnosno njezino je tijelo upravo čudov-ište, mjesto čudesnoga koje je zastrašujuće i opasno. No radikalna, abjektna Drugost njezina tijela nije tek unutrašnja, psihička sposobnost za transgresiju granica ljudskoga, nego je u posljednjoj etapi sekularnoga (i afektivnoga) konstruiranja ključan upravo izvanjski marker njezine čudovišnosti prema kojemu ju je moguće razlikovati od netransgresivnih i nesubverzivnih tijela, odnosno subjektiviteta, te mu je u stoga u Kriminalnoj praksi posvećeno i najviše prostora.

\section{Discipliniranje Zla}


Premda je vještica opasna sama po sebi jer narušava granice dopuštenoga i mogućega, dok je istodobno dijelom zajednice kojoj nanosi štetu i kojoj prijeti, a izvanjskim izgledom ne odudara od običnoga i ljudskoga, što je vidljivo iz iskaza svjedoka i tužitelja na samim suđenjima u sačuvanim zapisnicima, pravni diskurs smatra je devijantnom i opasnom ponajprije zbog njezine združenosti s muškim i moćnim đavlom, koji je njezinim stvarnim Gospodarem. Pred tom je neuhvatljivom i svemoćnom đavoljom „stranošću”, koja dopire iz registra mimo simboličkoga, pravni sustav posve nemoćan jer je nemoguće sankcionirati i korigirati nešto što je po svojoj danosti isključivo fluidno, što je sublimno Zlo. On je istodobno i bestjelesan i utjelovljen, bivajući i stranim tijelom unutar ljudskoga tijela i nepredvidljivim prodorom u sebstvo i fenomenom izvana koji prodire u društvenu teksturu. Vrag izaziva užas jer navješćuje, označava opasnost od uništenja i to podjednako fizičkog tijela, subjektiviteta i društva. Njegova nepredvidljivost, nestalna pojavnost i neuništivost, to jest odsutnost smrtnosti, za razliku od vještica, izazivaju strah upravo stoga jer se od njega nije moguće posve obraniti: on je istodobno i sva tijela i nijedno tijelo. Ili, kako kaže Lacan: „Stvar karakterizira činjenica da nam ju je nemoguće zamisliti” (Ethique 125), a što se iščitava iz samih zapisnika u kojima osumnjičene žene, na inzistiranje ispitivača, vraga neprestano imenuju drugim imenom i opisuju ga na posve drukčije načine, od onoga što čini do toga kako je odjeven, on izmiče opisu i bilo kakvoj konceptualizaciji. Vrag nije samo inverzija reda i pravde pa i simboličkoga oca (usp. Lacan, Écrits 321) koji jamči sigurnost i stabilnost simboličkoga, on je reprezentacija kaosa i poništava sva pravila i svaki zakon te deregulira žudnju i izmješta je u polje nedopuštenoga i tabua. Robert Muchembled smatra da je đavao od 15. stoljeća nadalje, osobito u doba masovnih progona vještica i razvoja demonologije, zauzimao poziciju jednako udaljenu od ljudskoga kao i Bog, jednako daleku i nepojmljivu kojoj je bio potreban bliži i ljudskiji supstitut (49)! ${ }^{[13]}$ To je jedan od razloga zašto je pravno discipliniranje Zla preusmjereno na dohvatljiva i poznata ženska tijela, i to preko svojevrsnoga transfera. Za razliku od Freuda koji je isprva transfer definirao kao izmještanje afekta s jedne ideje na drugu (562), Lacan smatra da transfer, premda se može manifestirati kao snažan afekt, nije povezan s afektima, nego izvire iz simboličkoga, dakle prostora zakona, kulture, društva i intersubjektivnih odnosa (Écrits 225). No cijela je Kriminalna praksa, zakon kao dio simboličkoga registra, afektivno obilježena, pa ju je moguće čitati kao uspostavljanje novih odnosa moći zamjenom, transferom jednog objekta afekta straha - vraga - drugim objektom 
- vješticama, na što ukazuje cijela procedura torture, ali podjednako i funkcija vještice u društvu koju je moguće iščitati iz zapisnika sa suđenja, a to je njezina Drugost za cijelu zajednicu na koju se preusmjeravaju sve negativne, „teške” emocije i afekti. Vještice su reprezentirale sigurno i stabilno mjesto na koje se moglo projicirati svaku fantaziju, štetu, konflikt ili pak nerazriješenu osobnu emociju zahvaljujući kolektivnoj afektivnoj atmosferi straha, a koja je bila politički i ideološki konstruirana i podržana. Ili, kako bi rekla Sarah Ahmed, vještice su bile objekti na koje su se projicirala različita afektivna stanja zajednice koja su se potom njima vraćala kao glavnim „krivcima” za teške emocije, odnosno vještice su reprezentirale središnje mjesto interkorporalnosti afekata (usp. Ahmed).

\section{Tortura kao praksa odznačivanja}

Premda je tortura bila dijelom istražnoga postupka i ranije, jer se u zapisnicima sa suđenja vješticama tijekom 15. i 16. stoljeća pronalaze opisi postupka i njihova priznanja nakon mučenja, sve do početka 17. stoljeća ona nije bila stalnim dijelom zakonske procedure i dotad je bilo moguće i takozvano čišćenje od optužbi, odnosno presude su mogle biti, premda rijetko, i oslobađajuće ${ }^{[14]}$ No od dvadesetih i tridesetih godina 17. stoljeća tortura postaje jedinim istražnim postupkom (usp. Bayer 237), a u doba masovnih progona usredotočena je manje na maleficij, odnosno štetu koja se nanosi „ljudima i stoci”,[15] a znatno više na demonski aspekt čarobnjaštva, dakle teološki aspekt, odnosno na predodžbu da se vještice „zapisuju đavolu”, pri čemu đavao sam izmiče označivanju, a vještice su dijelom njegove zastrašujuće i subverzivne skupine. Glavne formulacije u optužnicama tada su bile da je optuženica „sklopila ugovor s đavlom” te da je „spolno općila s đavlom”, što je još jedan od aspekata vještičje čudovišne Drugosti: nedisciplinirana, nekontrolirana pa time i izopačena seksualnost, to jest odnos s nečim/nekim što je reprezentacija svake abominacije, čemu je tijekom torture, kao i u samome zakonu, dano mnogo prostora. Nedopušteni, neproduktivni višak ženskoga užitka, jouissance, postaje važnim toposom samoga imaginarija, ali i sudskih/zakonskih sankcija.

Od 1699. povod procesu nije više iskaz „oštećene” osobe nego iskazi dobiveni torturom tijekom koje se ustrajavalo na popisu članica đavolje družbe te su ti iskazi postali jedinom dokaznom osnovom optužbe protiv novih vještica! ${ }^{[16]}$ Tako se na primjer u procesu iz 1733. protiv Margarete 
Kuljanke navodi da je treba podvrgnuti torturi kao vješticu „budući da imade dovoljno smrću ovjerenih dokaza" (Bayer 615), što je rezultiralo njezinim dugotrajnim mučenjem, a u konačnici i osudom da bude živa spaljena, što je čak i u onodobnome kontekstu bila okrutna smrt, dok je „milostiva” smrt uključivala dekapitaciju prije spaljivanja.

Premda su detaljna pitanja tijekom torture propisana Kriminalnom praksom, sama procedura određena je pravilima koje je razradio procesualist Ivan Kitonić u svojem djelu Metodičko vođenje sudskog procesa iz 1619., a na koje se obilno poziva u zapisnicima sa suđenja vješticama, kao i u drugim procesima u Hrvatskoj sve do kasnoga 18. stoljeća, i koji donosi jasnu klasnu stratifikaciju institucionalnoga osvajanja i obilježavanja tijela. Naime, Kitonić ističe da iako tortura nije predviđena nikakvim pravnim propisima, ona se primjenjuje na sudovima slobodnih gradova, a „najviše u procesima protiv seljaka” (contra rusticos), dok se plemstvo ne može podvrgnuti torturi osim ako nije zatečeno na mjestu zločina (nav. prema Bayer 260-61), čime se precizno određuju tijela koja treba disciplinirati i modificirati, regulirati i koja mogu biti obilježena odnosno koja mogu biti Drugost. Prema tome se može zaključiti da je institucionalno osvajanje tijela pratilo društvenu hijerarhiju moći i kanaliziralo kolektivnu atmosferu tjeskobe i straha na neka, uglavnom ženska i već statusnom pripadnošću podređena tijela.

Sama procedura torture bila je srodna onima na bečkim i praškim sudovima (Bayer 262-63), kao uostalom i na drugim sudovima diljem Europe, osim jednog načina torture koji u Hrvatskoj nije postojao, a to je tormentum insomniae, deprivacija sna, koji se često primjenjivao u europskim procesima te je bio iznimno učinkovit, ali manje okrutan od torture isključivo tijela na koju su fokusirani hrvatski procesi. Tortura je u hrvatskim procesima započinjala vizualnom reprezentacijom mučila koja su optuženici trebala navijestiti bol i patnju koje je očekuju te je motivirati da što prije prizna sve za što je se tereti. Ukoliko optužena ne bi odmah priznala zločin vještičarstva, slijedila je gradijentna tortura: stiskanje palaca (compressio pollicum), potom vezivanje ruku (ligatura manuum), nakon toga stavljanje „španjolske čizme” (ocrea hispanicum u hrvatskim zapisnicima) pa tortura oštrim željeznim šiljcima, a najjezivija i posljednja sprava za mučenje su bile ljestve (scalae, u jednom zapisniku i lojtre) na kojima bi se optuženu rastezalo sve dok ne bi priznala ili izgubila svijest, a nerijetko i preminula. 
S obzirom na to da su propisi Kriminalne prakse bili utemeljeni na predodžbi o vještičjem ugovoru s demonom te postojanju ili pisanoga ugovora (koji nije pronađen ni u jednom hrvatskome procesu) ili usmenoga ugovora koji je potvrđen vražjim potpisom na koži vještice, prvi dio procedure, koji je zapravo prethodio torturi, ali joj je bio i dijelom, usmjeren je na pretraživanje tijela te uklanjanje đavoljega znaka izrezivanjem tog komadića kože osumnjičene žene, a što je bilo smatrano dokazom o sklopljenome ugovoru, koji se prilagao sudskome spisu. Kako bi krvnik pronašao đavolji pečat, najčešće madež ili mrlju na koži, osumnjičena se žena morala posve razodjenuti, potom bi je posve izbrijali, uključujući i njezin „sram” - zapisničarski termin za vaginu koji reflektira odnos prema ženskome tijelu - a zatim bi je krvnik detaljno pregledao[17] U nekim europskim državama ili regijama postojali su svojevrsni specijalisti za takve preglede - najčešće liječnici, kirurzi ili pak starije žene, matrone, čijim su se angažiranjem u procesima nastojale izbjeći manipulacije ili zloporabe, ali i, ne manje važno, optuženim ženama osigurati profesionalan, a time i manje ponižavajući tretman, čega u hrvatskim procesima nema: tijelo žene mora biti posve poniženo i rastavljeno, zapravo osvojeno i preuzeto od moćne i sveprisutne, neoznačene i nespoznatljive Stvari. Pečati su tako pronađeni i izrezani s različitih dijelova tijela: s palca desne noge, s leđa, s grudiju, bedara, jezika, čak i s vaginalnoga područja, što i nije neobično s obzirom na predodžbu da je ugovor s đavlom podrazumijevao i spolni odnos.

Iz zapisnika doznajemo i o predodžbama o vještičjem tijelu koje nisu regulirane pravnim diskursom Kriminalne prakse, nego prodiru iz teološkoga/demonološkoga diskursa u proceduru sekularnih sudova, i koje se odnose upravo na đavolju kontinuiranu prisutnost podjednako na tijelu vještice i u njemu, poput predodžbe o „čarobnjaštvu šutnje” (maleficium taciturnitatus), koje im je omogućavalo neosjetljivost na bol tijekom torture $!^{[18]}$ Ta je predodžba o vješticama koje ne osjećaju fizičku bol, čime se izmještaju iz ljudskoga, povezana s još jednom Kramerovom fantazmom o vješticama koje nisu u stanju pokazati ikakve osjećaje (jer su osjećaji pripadni isključivo ljudskome ), pa tako ni plakati, što se testira „pokusom sa suzama”, koji također ulazi u torturalnu proceduru hrvatskih sudova. ${ }^{[19]}$ Lyndal Roper smatra kako je u ranome novome vijeku uspostavljena hijerahizacija emocija, osobito u religijskome diskursu, pri čemu su važno mjesto imali bol i patnja, za što pronalazi utemeljenje u vizualnim prikazima i pisanim izvorima u kojima se opisuje žalovanje zbog muke Kristove, procesijama, a posebno u kultu Bogorodice kao simbola majke koja pati 
(205). Nasuprot tome stoji vještica čije tijelo nije sposobno ni za patnju ni za druge emocije sve dok ga se ne odznači, što u hrvatskim procesima započinje detaljnim pregledom tijela, a potom slijedi polijevanje blagoslovljenom vodom samog tijela i svih mučila jer se time nastojalo otjerati vraga kao njezina označitelja i moćnoga zaštitnika[20]

Pečat je tražen pokusom s pomoću igle kada bi krvnik na „sumnjiva” mjesta utisnuo iglu: ako krv ne bi potekla, a mjesto uboda ne bi izazvalo bol - to je bio znak, pečat koji bi krvnik izrezao. No budući da pronalaženje pečata i mjesta na tijelu koje nije osjetljivo na bol nije očito bilo posve jednostavno, žene su često bile podvrgnute torturi kako bi same pokazale mjesto đavoljeg potpisa i otkrile detalje o sklapanju ugovora, odnosno morale su uvjerljivo odgovoriti na pitanja propisana zakonom. Stoga su žene, kako bi iznijele koherentnu i prihvatljivu naraciju, najčešće pripovijedale o realnim događajima iz njihova života, ali koristeći se jezikom koji im je nametnut pravnim diskursom, odnosno jezikom koji od njih zahtijeva supstituiranje i pomicanje. Tako je, primjerice, Bara Petruša mučena u dva navrata kako bi sama pokazala demonski znak na vlastitu tijelu i kako bi supstituiranom naracijom, u kojoj stvarna osoba iz njezine svakodnevice postaje đavlom, potvrdila vlastitu izopačenost:

Budući da je gore izjavila da je vještica, ispitana je kako je ušla u taj vještičji stalež je li po kakvom vražjem znamenju na tijelu ili možda po pismu. Odgovara da ju je prošle jeseni o berbi Markaj po stražnjici opalio, i to na raskršću o prvome mraku. Toga je Markaja vidjela kao crnog psa. I zamolila je da bude puštena s mučila da to pokaže gdje ju je Markaj opalio, sama će pokazati gdje ju je opalio i zapečatio. Zato je iz naprijed navedenog razloga u šest poslije podne skinuta $s$ ljestava. I sama je pokazala izvršiocu pravde dva vražja pečata, a isti ih je izvršilac izrezao i pod zakletvom potvrdio da su to uistinu vražji pečati. (Bayer 677)

Isti mehanizam supstitucije, đavla, drugim označiteljem - stvarnom osobom iz najbliže okoline, najčešće vlastitim bračnim ili izvanbračnim partnerom - može se iščitati iz naracija osumnjičenih žena o „spolnom općenju s đavlom”, za koji su hrvatski sudovi pokazali neobično velik interes s nizom razrađenih potpitanja o izgledu i imenu đavla, njegovoj odjeći, mjestu i okolnostima u kojima se odnos dogodio te osobito o đavoljem penisu, „das Ding je uzrok najosnovnije ljudske strasti” (Lacan, Ethique 97). U torturalnom zapisniku procesa protiv Ane Sirkovice 1699. tako piše: „Veli da je s vragom dva puta na svojoj postelji sagriješila. Da je došao u podobi njena muža, ali da ga je 
ona odmah poznala jer mu je bio hladan" (Bayer 246). U procesu iz 1733. protiv Margarete Kuljanke zapisano je nakon prvog dijela torture sljedeće:

Vrag je dolazio k njoj po noći u spodobi njenog gospodara i u odijelu sličnom njegovome, više puta i po dvaput na noć, i na dan mlade večeri, napastujući je da će joj biti bolji nego njezin gospodar, samo neka ide u drugarstvo s vješticama. I otkako ju je to vrag napastvovao, u spomenutoj spodobi njenog gospodara - bilo je to pred neko 12 godina - odonda nije više rodila djece. (Bayer 615-16)

Njezina naracija u kojoj se koristi supstitucijom zapravo govori o seksualnom zlostavljanju koje je doživjela na feudalnome posjedu na kojem je radila kao služavka, o traumi koju je izjednačila s vlastitom transgresijom i o kojoj se inače ne govori te o sudskoj prisili da se tuđi prekršaj (u ovome slučaju njezina poslodavca) pounutri kao vlastiti. Isti mehanizam supstitucije označitelja i pounutrivanja tuđega prijestupa kao odraza vlastite kvarnosti, ponovno silovanja, prisutan je i u drugoj zabilježenoj naraciji Margarete Kuljanke nakon ponovljene torture: „Nadalje izjavljuje da je vrag s njome, u podobi njenoga muža, više puta spolno općio da je dva puta i u zatvor k njoj dolazio u podobi gospodina gradskog kapetana, i obećavao joj da će je osloboditi zatvora. On da nije imao toplog sjemena nego hladno, i da ga je ona poznala da je vrag, a ne onaj u čijoj je podobi navedenim prilikama k njoj dolazio" (Bayer 617).

Ti fragmenti naracija svjedoče ne samo o institucionalnome, ozakonjenome ponižavanju i mučenju ženskih tijela zbog njihove konstruirane demonske Drugosti, nego i o izvaninstitucionalnoj stvarnosti u kojoj se žene nekažnjeno seksualno zlostavlja, odnosno u kojoj postoji društveno odobreno pravo na žensko tijelo, kada su žene podjednako objekti i žudnje i straha, a što i u jednom i u drugom slučaju rezultira dopuštenim nasiljem nad ženama.

\section{7. „Subjekt nije osuđen na svoju svijest nego na tijelo” (Lacan, „Réponses” 8)}

lako institucionalno, diskurzivno konstruiranje i upisivanje Drugosti na tijelo/tijelu koje propisuje Kriminalna praksa nije izrijekom vezano uz rod, praksa u doba masovnih procesa ipak pokazuje da je glavnim mjestom osvajanja, discipliniranja i kažnjavanja bilo ponajprije žensko tijelo. Takvo je 
konstruiranje ženskoga tijela kao stranoga i čudovišnoga, kao tijela koje ima moć da uništi, imalo dugotrajne i jezive posljedice, a cijeli se fenomen masovnih progona iz suvremene perspektive može činiti iracionalnim i fantazmatskim. No iz psihoanalitičke perspektive može ga se tumačiti kao radikalan, ali ne i nerazumljiv primjer ulaska u prostor simboličkoga, zakona i društva, odnosno formiranja subjektiviteta za koje je nužan antagonistički Drugi, koji je u primarnom, dijadnome odnosu najčešće ženska Drugost pomoću koje se subjektova intraagresivnost izmješta ili projicira u polje društvenih odnosa, to jest pretvara je u interagresivnost. Kolektivna atmosfera straha, koji svoje izvorište ima u individualnom strukturiranju sebstva, a kojoj su pravni i teološki diskurs dali okvir i usmjerili je k ženskoj Drugosti te konstruirali vještičji imaginarij, praznila se i kanalizirala u javnim, ritualnim kažnjavanjima. Kulminacija institucionalnog, pravnog zaposjedanja tijela bilo je javno pogubljenje: transgresivno tijelo vještice koje je nekoć imalo moć i trag đavolje prisutnosti sada je posve odznačeno, desimbolizirano i vraćeno ljudskome, ponovno osvojeno, obilježeno pravnim diskursom, izmučeno i izloženo pogledu zajednice.

Prije smaknuća na javnome mjestu ${ }^{[1]}$ pred okupljenim mnoštvom čitana je optužnica, osuda i dijelovi priznanja i to ne samo kako bi se demonstrirali uspostavljeni red i vladavina Zakona te stabilizirani simbolički poredak, nego i kao upozorenje svima koji bi mogli prekršiti neku od društvenih i pravnih normi. Izloženo žensko tijelo koje je torturom desimbolizirano, pa i depersonalizirano, izaziva strah i tjeskobu jer prikazuje prodor realnoga, brutalne fiziologije mesa, krvi, organa, kostiju - u prostor simboličkoga i uređenoga, reguliranoga svijeta. Pogubljenje spaljivanjem bilo je uobičajenom kaznom, no ako bi se optužena pokajala, tada bi je dekapitirali prije spaljivanja, a u slučajevima kada je zločin bio suviše težak, žene su spaljivane žive. U rijetkim slučajevima, kao znak osobite milosti, o vrat bi im bila obješena vrećica s barutom koja bi ih usmrtila prije nego ih vatra posve proguta. Javno pogubljenje bilo je važnom reprezentacijom moći i pobjede nad demonskim Drugim, čak i u slučajevima kad su žene preminule u zatvoru tijekom torture: njihova tijela prevezena su do Zvezdišča, optužnica i presuda pročitane su, a mrtva bi žena bila spaljena. Radikalno kažnjavanje i poništavanje ženskoga tijela, njegovo vraćanje u predrealno stanje, u stanje onkraj organizacije u organizam, osigurava zajednici prividnu pobjedu nad muškim, đavoljim Zlom koje je evazivno i fluidno, samim time i nekažnjivo, a pravnome diskursu i sekularnoj vlasti omogućuje potiskivanje teološkoga diskursa i crkvene ingerencije nad tijelima u pozadinu. 
Pravni diskurs, koji je bio isključivo muškim diskursom moći u ranome novom vijeku, prvo konstruira čudovišna ženska tijela utiskujući im đavolji znak, muški otisak, a potom ih procesuira, muči i odznačuje kako bi preuzeo vlast i uspostavio vlastiti red i zakon. No lokalnim muškim igrama moći kojima su glavnim objektima u hrvatskim procesima bile žene na kraj ipak staje žena na poziciji moći, carica Marija Terezija, koja isprva 1752. zahtijeva da joj se dostave spisi o procesima protiv vještica na daljnje ispitivanje, a Općim zakonom o kaznenom sudskom postupku iz 1768. suđenja vješticama stavlja isključivo pod vlastitu ingerenciju, što je u Hrvatskoj označilo kraj masovnih progona.22]

\section{Bibliografija}

Ahmed, Sara. The Cultural Politics of Emotion. Edinburgh University Press, 2014.

Bayer, Vladimir. Ugovor s đavlom. Procesi protiv čarobnjaka u Evropi, a napose u Hrvatskoj. Treće izdanje, Zora, 1982.

Behringer, Wolfgang. Witchcraft Persecutions in Bavaria: Popular Magic, Religious Zealotry and Reason of State in Early Modern Europe. Cambridge UP, 1987.

Biti, Ozren. „Kamo s tijelom? Od kartezijanskog naslijeđa do studija tijela”. Etnološka tribina, god. 34, br. 41, 2011, str. 7-14.

Clark, Stuart. Thinking with Demons: The Idea of Witchcraft in Early Modern Europe. Oxford UP, 1997.

Cohn, Norman. Europe's Inner Demons. The Demonization of Christians in Medieval Christendom. Pimlico, 1993.

Davidson, Jane. The Witch in Northern European Art, 1470-1750. Luca, 1987.

Evans, Dylan. An Introductory Dictionary of Lacanian Psychoanalysis. Routledge, 1996.

Federici, Silvia. Caliban and the Witch. Women, the Body and Primitive Accumulation. Autonomedia, 2004.

Fink, Bruce. Lakanovski subjekt. Između jezika i joiussance. Kruzak, 2009. 
Freud, Sigmund. „The Interpretation of Dreams”. The Standard Edition of the Complete Psychological Works of Sigmund Freud, Volume V (1900-1901): The Interpretation of Dreams (Second Part) and On Dreams, uredili James Strachey i Anna Freud, Hogarth Press, 1953, str. 339-626.

Ginzburg, Carlo. „Deciphering the Sabbat”. Early Modern European Witchcraft: Centers and Peripheries, uredili Bengt Ankarloo i Gustav Henningsen, Clarendon, 1990, str. 121-37.

Hillman, David i Carla Mazzio, urednici. The Body in Parts. Fantasies of Corporeality in Early Modern Europe. Routledge, 1997.

Lacan, Jacques. Écrits: A Selection. Tavistock, 1977.

Lacan, Jacques. Le Séminaire. Livre VII. L'éthique de la psychanalyse, 1959-1960. Seuil, 1986.

Lacan, Jacques. Le Séminaire. Livre XXI. Les non-dupes errant. Neobjavljeno, 1973-1974.

Lacan, Jacques. „Le stade du miroir comme formateur da le fonction du Je”. Écrits, 1966, str. 93100.

Lacan, Jacques. „Réponses à des étudiants en philosophie sur l'objet de la psychanalyse”.

Cahiers pour l'analyse, br. 3, 1966, str. 5-13.

Laszowski, Emilije. „Progon vještica u Turopolju”. Vjestnik Kr. hrvatsko-slavonsko-dalmatinskog zemaljskog arkiva, br. 16, 1914, pp. 196-208.

Levack, Brian P. The Witch-Hunt in Early Modern Europe. Pearson, 2006.

Monter, William. „Devil's mark”. Encyclopedia of Witchcraft. The Western Tradition, uredio Richard M. Golden, ABC-Clio, 2006, str. 275-77.

Muchembled, Robert. Đavao od XII. do XX. stoljeća. Jedna priča. Pelago, 2010.

Owens, Margaret E. Stages of Dismemberment. The Fragmented Body in Late Medieval and Early Modern Drama. University of Delaware Press, 2005.

Roksandić, Drago. „Izlazak izvan zidina. 18. stoljeće”. Povijest grada Zagreba - Knjiga I (Od prethistorije do 1918), uredili Ivo Goldstein i Slavko Goldstein, Novi liber, 2012, str. 200-50. 
Roper, Lyndal. Oedipus and the Devil. Witchcraft, Religion and Sexuality in Early Modern Europe. Routledge, 1994.

Sawday, Jonathan. The Body Emblazoned. Dissection and the Human Body in Renaissance Culture. Routledge, 1995.

Scholz Williams, Gerhild. „Demonologies”. The Oxford Handbook of Witchcraft in Early Modern Europe and Colonial America, uredio Brian P. Levack, Oxford University Press, 2013, str. 1-11.

Stephens, Walter. Demon Lovers: Witchcraft, Sex, and the Crisis of Belief. University of Chicago Press, 2002.

Sullivan, Margaret. „The Witches of Dürer and Hans Baldung Grien”. Renaissance Quarterly, god. 53 , br. 2, 2000, str. 333-401.

Tkalčić, Ivan Krstitelj. „Izprave o progonu vješticah u Hrvatskoj”. Starine XXV, 1892, pp. 1-102.

Voltmer, Rita. „Witch Hunts”. Encyclopedia of Witchcraft. The Western Tradition, uredio Richard M. Golden, ABC-Clio, 2006, str. 1209-14.

Zika, Charles. „Goat”. Encyclopedia of Witchcraft. The Western Tradition, uredio Richard M. Golden, ABC-Clio, 2006, str. 446-47.

Zika, Charles. „Images of Circe and Discourses of Witchcraft, 1480-1580”. Zeitenblicke: OnlineJournal für die Geschichtswissenschaften, god. 1, br. 1, 2002. Zeitenblicke, www.zeitenblicke.de/2002/01/zika/zika.html. 
[1] Ovaj tekst financirala je Hrvatska zaklada za znanost u okviru projekta Naracije straha: od starih zapisa do nove usmenosti (IP-06-2016-2463).

[2] Demonološki traktati (demonologies) ili „teorije vještičarstva” (witchcraft theories), kako ih nazivaju Walter Stephens i Stuart Clark, ranonovovjekovni su žanr, utemeljen sredinom 15. stoljeća, odnosno kompendiji koji znanstvenim, „racionalnim” aparatom teološkoga i filozofskoga diskursa razmatraju različite aspekte kontakta i interakcije vraga/Sotone i demona s ljudima, najčešće ženama optuženima da su vještice, te njihove pravne i medicinske konzekvence (usp. Scholz Williams 1-11). U Hrvatskoj su također bili dobro poznatim i konzultiranim žanrom, o čemu svjedoče i prva izdanja nekih od njih, poput najozloglašenijeg i najkorištenijeg, Kramerovog inkvizicijskog priručnika Malleus maleficarum, koji se nalaze u Nacionalnoj i sveučilišnoj knjižnici u Zagrebu.

[3] Premda su i drugdje u Europi, uglavnom na području nekadašnjeg Svetog Rimskog Carstva (Levack 211 i dr.), u procesima protiv vještičarstva osuđivane pretežno žene - od procijenjenoga broja između 30000 i 90000 ljudi spaljenih zbog vještičarstva (Voltmer 1210) čak tri četvrtine bile su žene (usp. Behringer), u kontinentalnoj Hrvatskoj u doba masovnih progona vještičarstvo je smatrano gotovo isključivo ženskim zločinom i postoji tek jedan sačuvani zapisnik koji svjedoči o procesu protiv muškaraca.

[4] Urednice opsežnoga zbornika Sex and the Body. 1500 to the Present, Sarah Toulalan i Kate Fisher u svojem uvodnom tekstu ističu kako je promjena od vjerske prema sekularnoj konceptualizaciji tijela, a koju smještaju pretkraj 17. stoljeća, svejedno i dalje bila znatno, a ponekad i skriveno, zamućeno, obilježena crkvenom, počesto i nasilnom kontrolom seksualnosti (15).

[5] Prema psihičkim registrima - imaginarnom, simboličkom i realnom - Lacan uspostavlja i jasnu distinkciju i između imaginarnog, simboličkog i realnog tijela, pri čemu je, pojednostavljeno, realno tijelo zapravo fragmentirano tijelo, Lacanovim rječnikom corps morcelé, odnosno skup organa, tekućina, procesa i produkata; imaginarno tijelo je, uvjetno, pokušaj ovladavanja fragmentiranim tijelom doživljavanjem cjelovitosti što se odvija u stadiju zrcala („Le stade du miroir” 93 i dr.) kada nastaje slika, predodžba o cjelovitosti koja dolazi izvana te je stoga nestabilna i promjenjiva, ali i 
predstavlja normativni ideal, dok je temeljno obilježje simboličkog tijela njegova označenost Drugim koji je pravi „posjednik” tijela putem označitelja, odnosno tijelo tako postaje tek učinkom, efektom označivanja. Da bi tijelo uopće postalo tijelom potrebni su organizam, slika i jezik (koji redom pripadaju realnom, imaginarnom te simboličkom registru) te su povezani Boromejskim čvorom zajedno konstituirajući subjekt.

[6] Sociolozi su tijelo tretirali kao nešto što pripada prirodnome svijetu (usp. Biti 9), što je kod Lacana registar imaginarnoga, a antropolozi su više ukazivali na simboličke reprezentacije tijela i utjelovljenost društvenih i kulturnih praksi (npr. pionirski radovi Mary Douglas, Lévi-Straussa i Marcela Maussa i dr.), što je kod Lacana vidljivo u simboličkome registru.

[7] Naime, slikarstvo potkraj 15. i početkom 16. stoljeća, ponajprije na crtežima, grafikama i drvorezima autora iz južne Njemačke poput Hansa Baldunga Griena, Albrechta Altdorfera, Albrechta Dürera, a kasnije i iz flamanske i nizozemske škole poput Lucasa Cranacha, Pietera Brueghela, Hieronymusa Boscha i dr., nastaje radikalno nova ikonografija vještičarstva, dotad posve neuobičajena i za književnu i za izvanknjiževnu zbilju, ali i za vizualne umjetnosti. Tako je po prvi put vještičarstvo prikazano kao isključivo ženski grijeh na drvorezima Hansa Baldunga, objavljenima u više od dvadeset izdanja jednoga od najutjecajnijih demonoloških traktata, De lamiis et phitonicis mulieribus Ulricha Molitora iz 1489., koji su potom obilno kopirani i varirani diljem Europe, osobito u tiskanim izdanjima demonoloških tekstova različitih autora. Na tim se Baldungovim drvorezima, između ostaloga, pojavljuje po prvi puta i prikaz vještičjega kotla, kasnije osnovnog dijela stereotipnoga kôda vještičarstva podjednako u vizualnim umjetnostima kao i u (usmenoj i pisanoj) književnosti (usp. Davidson; Sullivan; Zika, „Images”; Muchembled i dr.). Dürerove grafike uspostavljaju otad važeći dvojni vizualni stereotip vještica: ili su mlade, putene i zavodljive poput onih prikazanih na grafici Četiri vještice iz 1497., ili su stare, oronule i ružne poput one koja jaše na jarcu prikazane na slici iz 1500. Taj stereotip potom ulazi i cirkulira podjednako u usmenoj kao i pisanoj književnosti, ali i u cijelome kulturnome imaginariju. Kako smatra Muchembled, u vizualnim umjetnostima koje odražavaju društvenu stvarnost „glavna opsesija je spolnost . . . No podjednako se opsesivno ističu staračka nemoć i smrt. Erotični prizori istovremeno su morbidni, jer i nad najljepšim ženskim tijelima lebdi sjena propadanja i smrti. Seksualnost je prepuna razorne simbolike, kao u . . . slučajevima djevojaka u zagrljaju kostura. Umjetnici su, 
možda i nesvjesno, izrazili preokupacije crkvenih dostojanstvenika, a vjerojatno i velikaša koji su kupovali njihova djela, i čarobnjaštvo prikazali povezivanjem ženskog lika sa smrću" (63).

[8] O utjecaju crkvene provincijalne sinode u Trnavi 1611., čiji je cilj bio provesti propise općeg crkvenoga tridentskog koncila (1545.-1563.), a koji su se ticali i čarobnjaštva, to jest vještičarstva, na odredbu koju je donio Hrvatski sabor između 1609. i 1625. o strogom (rodno definiranom) progonu „vještica, čarobnica i trovateljica” („strigas, sagas et veneficas”), odnosno o vjerojatnoj refleksiji crkvenoga prava na sekularno zakonodavstvo više u Bayer 284-90. Ta je odredba pripadala takozvanom običajnome pravu i prethodila je Zakoniku o kaznenom postupku kralja Ferdinanda III., koji je pak zrcalio ne samo lokalne običajno-pravne prakse, mnogo starije od samoga Zakonika, nego i cijeli europski složeni pojam zločina čarobnjaštva, time i vještičarstva, uz specifičnu iznimku - maleficij nije više bio temelj za progon, nego „odavanje” imena sudionica u vještičarstvu, a koje se događalo tijekom torture.

[9] Iznimku čine engleski procesi protiv vještica u kojima nema spomena o đavoljem, demonskome znaku, nego se u istražnome postupku pretražuje tijelo vještice kako bi se pronašao takozvani vještičji znak, anomalija na tijelu poput treće bradavice i sl. Njezino je tijelo već fizičkim karakteristikama drukčije od „normalnoga”, ljudskoga tijela, ali nije dodatno označeno demonskom Drugošću, za razliku od većine kontinentalnih procesa.

[10] Premda je strah od fragmentiranja tijela najradikalniji u vještičjem imaginariju kasne renesanse i ranoga novog vijeka, a onda i u pravnome diskursu, fascinacija tijelom u komadima vidljiva je i u različitim dijelovima izvan-vještičje stvarnosti: od znanstvene kategorizacije i klasifikacije, medicinske anatomizacije koje su upravo u tom razdoblju doživjele uzlet, do reprezentacija u vizualnim umjetnostima ili pak književnosti (usp. Owens; Hillman i Mazzio; Sawday).

[11] Lacan radikalizira ideju egzistencije kao jezika, tvrdeći da egzistencija uopće ne bi bila moguća da nema glagola biti: „Biće koje govori . . . je pleonazam, zato što postojanja ima samo zahvaljujući govorenju. Da nema glagola biti uopće ne bi bilo postojanja” (Lacan, „Les non-dupes”, nav. prema Fink 213).

[12] O letovima vještica piše već Apulej u Zlatnom magarcu, u srednjovjekovnoj književnosti vila Morgan le Fay također ima sposobnost letenja i pretvaranja u drugu osobu ili životinju, a samo se 
vjerovanje u teološkome diskursu prvi put sankcionira u Canon Episcopi već početkom 10. stoljeća. Kasnije se neprestano dodaju novi detalji vještičjega leta, pa se tako u Errores Gazariorum (pri čemu se Gazari odnosno Katari odnosi na sve heretike, a kasnije i na vještice) iz 1437. spominje da su demoni darovali novoprimljenim vješticama štap s mašću za letenje nakon inicijacijskoga obreda. Premda je u doba masovnih progona postojala i skeptična linija koja je osporavala mogućnost leta, poput Johannesa Niedera u Formicariusu, i koja ih je smatrala ili fantazijama ili nekom vrstom transa induciranog različitim biljem, najpoznatiji inkvizicijski priručnik, Malleus maleficarum, smatra ih stvarnima te Kramer nudi dva objašnjenja. Prvo je da ih transportira vrag ili da ih vrag u snu prenosi na mjesto okupljanja, pri čemu duša napušta tijelo, a druga je metoda uključivala nanošenje masti spravljene od ubijene djece, čime se uključuje i infanticid u imaginarij. Norman Cohn smatra da je reprezentacija sabata koja je svoja stalna mjesta dobila početkom 15. stoljeća u pravnom, teološkom i demonološkom diskursu mnogo ranija, i da su je kao negativnu sterotipizaciju koristili već Rimljani protiv prvih kršćana, potom tijekom srednjeg vijeka kršćani protiv Židova i heretika, a u vrijeme masovnih progona samo su joj pridani novi, zlokobniji toposi koji zrcale i pučka vjerovanja, a ne samo diskurse moći (usp. Ginzburg 121-37).

[13] Muchembled smatra da su pučka vjerovanja, time i predodžbe, o đavlu u doba kasne renesanse i ranoga novog vijeka znatno izmijenjene, od ljudskijeg prema primordijalnome, arhetipskom Zlu, upravo pod utjecajem reformacije i protureformacije, odnosno demonologije koja je proizvela zamjenski, ljudski lik vještice kao mjesto pražnjenja straha (49-122).

[14] Zanimljivo je primijetiti da je posljednji zabilježeni slučaj blagoga procesa u kojem je osobi dopušteno „čišćenje od optužbi” vođen protiv muškarca, jednog od neznatne nekolicine koje se u Hrvatskoj uopće procesuiralo zbog vještičarstva i čarobnjaštva, a što spominje zagrebački kanonik i katedralni arhiđakon Benko Vinković u izvještaju o vizitaciji zagrebačkih župa 1622., zapisavši da je neki Mlinarić pušten „cum conditione dimissus fuisset ut se judicialiter ab objecto sibi crimine purgasset" (Tkalčić 4).

[15] Prema sačuvanim izvorima, čini se da je do 1698. maleficij bio najvažnijim elementom optužbi, iako je u nekim slučajevima poiman i mimo stroge definicije o nanošenju teške štete, pa se tako iz zapisnika može razumjeti da je maleficij i „davanje čarolije” nekoj ženi da bi joj suprug bio vjeran (proces protiv M. Sikirić iz 1651., Tkalčić 9), otimanje ljudi da bi ih se odvelo na sabat (proces 
protiv Bare Tunčić iz 1639., Bayer 295-96; proces protiv Jele Kovačić iz 1657., Tkalčić 10) ili naprosto izazivanje straha, za razliku od većine europskih procesa u kojima maleficij ostaje središnjim mjestom optužbi i u doba masovnih progona, uz sve ostale predodžbe iz vještičjega imaginarija.

[16] Upravo je takav dokazni, to jest istražni postupak - odavanje imena sudionica u vještičarstvu tijekom torture - pokrenuo masovne procese, a iz sačuvanih zapisnika može se zaključiti da ih je najviše bilo u Zagrebu 1699., u Varaždinu 1717. te u Turopolju 1733. i 1734., koji su pokrenuti nakon torture Margarete Kuljanke (Bayer 254; Laszowski 196-208).

[17] Takav pristup ponajprije ženskome tijelu i njegovome detaljnome pregledu nije bio uobičajen dio torture osim u slučajevima vještičarstva, a preporuku o posramljujućem i porobljavajućem postupku propisao je Kramer u Malleus maleficarum te je otad uvršten i u procedure većine europskih sekularnih sudova.

[18] Čarobnjaštvo šutnje prvi put spominje Kramer u Malleus maleficarum u III. dijelu, pod trinaestim pitanjem „O točkama koje sudac mora razmotriti prije službenog ispitivanja u mjestu pritvora i mučenja. Osma radnja”, a koje potom ulazi u repertoar vjerovanja koja utječu na proceduru torture i crkvenih i sekularnih sudova.

[19] Pokus sa suzama navodi se u procesu protiv Ane Klarić iz 1702., koju tijekom torture pitaju „zašto joj suze neće teći” (Laszowski 241).

[20] Osumnjičena Jela Ptičekovka u procesu 1743. na torturi govori kako nije ranije htjela ništa priznati jer joj „vrag ni dal do pol trete vure povedati”, a tek kad su je polili blagoslovljenom vodom „onda je vrag kak ti jedna muha od nje skočil” (Tkalčić 30).

[21] Tortura se u Zagrebu, točnije Gradecu, odvijala „ispod gradske vijećnice grada Zagreba”, kako stoji u zapisniku procesa protiv Margarete Drapuške 1747. (Bayer 652), dakle u kompleksu koji se nalazi današnjoj Ulici sv. Ćirila i Metoda 5, između Kuševićeve i Freudenreichove ulice te Markova trga, dok je mjesto pogubljenja dugo bila četverokutna kula iznad „novih” Mesničkih vrata (Roksandić 217), a glavnim je mjestom smaknuća bilo Zvezdišče, na početku današnjeg Tuškanca. 
[22] Hrvatski sabor 26. ožujka 1756. donosi zakonski članak po naredbi carice Marije Terezije prema kojemu svaku osudu protiv vještičarstva mora potvrditi carica osobno. Zadnji sačuvani zapisnik protiv vještice iz Križevaca, Magdalene Logomer Herucine, datiran je s 1758. godinom; nju po nalogu Marije Terezije odvoze u Beč i na kraju oslobađaju optužbi (usp. Bayer 747-49).

\section{(c) (i) (9)}

Creative Commons Attribution-NonCommercial-NoDerivatives 4.0 International License 